\title{
CORRESPONDENCE
}

\section{The coal of today}

SIR - The content of the leading article "A strategy for coal"' (Nature 25 February, p.636) indicates a view based on out-dated knowledge of the coal industry. The economic arguments used ignore, for example, the fact that British coal is the most competitive in the European Community. The latest published coal production cost comparisons (for 1980) are:

$\begin{array}{lc} & £ \text { per tonn } \\ \text { Belgium } & 61 \\ \text { France } & 45 \\ \text { West Germany } & 44 \\ \text { UK }(1980 / 81) & 35\end{array}$

The article mentions the design of microcircuits as if this was a world apart from coal mining. In fact, Britain's technologically advanced coal industry extensively uses computers, microprocessors, transducers, lasers and other modern aids. There is obviously no future in the microtechnology unless there are industries like coal to use the products. The National Coal Board and private enterprise manufacturers have successfully designed and introduced computerized control and monitoring systems for colliery operations and these are creating considerable interest overseas.

Longwall mining technology was pioneered in Britain and equipment sales remain significant export earners - and have resulted in record-breaking colliery performances in the United States, South Africa and Australia. There are many other examples showing that our indigenous coal production is serving Britain well - and it will need to do so in the future. Incidentally, the Australian exports mentioned in the Nature article include a high proportion of opencast coal which is also profitably produced in Britain. ROBERT HUNT Dowty Group, Cheltenham, UK

\section{Doves in false garb}

SrR - Having read more than once your leading article of 18 February (p.542) under the condemnatory title above, I am still puzzled that you provide no evidence, by way of argument, to justify the statement "The claim by the anti-nuclear movement of professional support is mostly a sham". The occasion you were commenting upon, the Conference of Professions for World Disarmament and Development, convened under the auspices of the World Disarmament Campaign, made no claim to speak officially for the major professional societies. But the attendance of several hundred professional people, and the rapid growth of specialist bodies such as Scientists Against Nuclear Arms (SANA), Medical Campaign Against Nuclear Weapons, and Teachers for Peace suggests that there are many who do agree in general terms that "the professions as such have a responsibility to alert the general public to the great issues that confront society". You seek to deny this, yet you accept in the very next sentence that "there is a sense in which professional people, acting individually, may be held to shoulder an extra responsibility for giving wider currency to their conclusions about important issues on which they have some special knowledge".

Why the emphasis on acting individually?
Why do you consider it "not respectable" for scientists of different disciplines to come together through SANA to pool their varied expertise relevant to the effects of nuclear war on Britain, and then to make known their conclusions based on this special knowledge? Why try to belittle the work of the Medical Campaign Against Nuclear Weapons and the Medical Association for the Prevention of War, who point out to their colleagues that nuclear war would be a medical catastrophe beyond reach of any cure, so that it becomes a professional duty to seek its prevention?

You complain that the major professional bodies "are needlessly indifferent to important public issues well within the spheres in which their professional competence could command respect"'. Yet you condemn, by implication, the work of the British Medical Association to study the medical effects of nuclear war, and the efforts within the teaching profession to direct attention to the role that education plays in forming public attitudes to other countries and to conflicts within and between countries. Do you not accept, for your own profession of journalism, some responsibility for the way in which the press and television treat major issues such as nuclear war and thus influence the formation of public opinions?

Christopher Meredith (Secretary, Scientists Against Milton Keynes, UK Nuclear Arms)

SIR - The leading article on the meeting of professional groups concerned with supporting nuclear disarmament makes a number of astonishing assertions (Nature 18 February, p.542). For instance it seems to question the right of the medical profession to express an opinion on the issue, claiming that

"Physicians have been consistently indifferent to the quality of health care (in Britain)"'. This suggestion is as insulting to the medical profession as it is unfounded.

The health care professions should and do have a special knowledge of the medical effects of nuclear weapons as have other professional bodies, such as architects, specialized knowledge of such matters as affect their sphere. It would seem entirely understandable, and we would submit entirely proper, that such organizations should undertake to publicize as widely as possible the full effects of the use of nuclear weapons.

The rapidly expanding Medical Campaign Against Nuclear Weapons, and no doubt the other professional groups represented at the meeting discussed in the article, reflect the widespread concern over the proliferation of nuclear weapons and the apparent increasing risk of their use. In the United States, professional bodies voice similar concerns. Thus a recent report of the American Medical Association stated "There is no adequate medical response to a nuclear holocaust".

Doctors and other professional organizations not only have a right but a duty to speak out on the subject of nuclear weapons and nuclear warfare. They do so in order to bring the facts to the attention of their colleagues, politicians and the general public and not, in the remarkable words of the leader, to capture any "mediaeval mystique". M. HARTOG, J.H. BAUMER, P.J. Fleming, M.J. HALl University of Bristol, UK
SIR - The views expressed in your leading article entitled "Doves in false garb" (Nature 18 February, p.542) were put forward provocatively enough to require reply.

You have allowed that "there is a sense in which professional people, acting individually, may be held to shoulder an extra responsibility for giving wider currency to their conclusions about important issues on which they have some special knowledge"'. Why must they be "acting individually"? Why, that is, when medical people act together, do you decry this as their "attempt to invest their legitimate causes with spurious authority . . . a deceit"'?

Medical people certainly have no entitlement to speak with any lofty authority. But we have seen people die of burns and crush injuries, and have had to repair terrible lacerations. There is always at such times the question "why need this have happened?", and physicians, surgeons and general practitioners alike bear, or should bear, prevention constantly in mind. For epidemiology prevention is the raison d'être. It means searching for any predisposing causes of disease or injury and proclaiming them when they are found. For many of us it is no longer tenable to act in this way where, say, chemical carcinogenesis, dietary causes of disease or accidents in the home are concerned, but to remain mute on the dangers of nuclear detonations. Psychiatrists especially are left with few illusions about human fallibility.

London, UK

STEWART BRITTEN

\section{A final word}

SIR - "The ereationists may have lost the battle in Arkansas but they are unlikely to abandon the war on which they are engaged" (Nature, 14 January, p.85).

Your journal has, for several months, lent itself as a battleground for this verbal brawl by continuing to publish letters from both sides, many of which do not (and cannot) contain any elements of scientific reasoning. This correspondence has degenerated into a discussion of the Bible as a source of artistic inspiration (A.J. Hollin, Nature, 18 February, p.548) and such fine points as the positioning of a comma in Luke's gospel (F.W. Cousins, Nature, 11 February, p.452). These authors clearly have a sense of the absurd.

Nature is a journal with a large and mixed audience which serves not only to publish important scientific findings, but also to inform scientists about political issues which are of particular interest to them. The Arkansas trial was clearly one such issue. That trial is now over, and scientists wishing to continue the discussion should now look to do so from a platform where they might be better able to inform and enlighten the general public. Does Dr Salthe (Nature, 11 February, p.452) really need to point out to a scientific readership the folly of the statement that "The scientific community does not consider origins of life a part of evolutionary theory"?

Serious discussion of mechanisms involved in evolution has a place in this journal. Advocates of God and Genesis should air their views elsewhere.

University of Alabama, USA

THIS correspondence is now closed - EDITOR 